\title{
PENGELOLAAN PIUTANG MURABAHAH PADA PERIODE SEBELUM DAN SAAT PANDEMI COVID-19: STUDI KASUS BANK XYZ
}

\author{
Maman Suhendra* 1); Inkana Janan Afra ${ }^{2)}$ \\ 1) msuhendra@pknstan.ac.id, Afiliasi (Politeknik Keuangan Negara STAN) \\ 2) 1302181274_inkana@pknstan.ac.id(Politeknik Keuangan Negara STAN)
}

\begin{abstract}
The Covid-19 Pandemic has impacted several sectors in the economy. One of the sectors that has been impacted relatively much severe is the banking sector particularly regarding the debitors' ability to pay their loan back to the banks. In response to this, the relevant authority then issued credit restructuring policy to mitigate this impact. This sudy aims to understand the loan management before the pandemic, the credit restructuring during the pandemic, and the effect of the credit restructuring in the financial reporting of Bank XYZ. Using the qualitative approach through a semi-structure interview and study on relevant documents, it is found that the credit restructuring affected the decrease on loan turn-over and return on assets as well as the increase on average loan ages and non-performing loan ratio.
\end{abstract}

Keywords : Covid-19 Pandemic, murabahah loan, credit restructuring

\begin{abstract}
Abstrak
Pandemi Covid-19 telah memberikan dampak pada beberapa sektor dalam perekonomian. Salah satu sektor perekonomian yang terdampak relatif dalam adalah sektor perbankan utamanya terkait dengan kemampuan nasabah/debitur dalam mengembalikan pinjaman kepada perbankan. Sehubungan dengan hal ini, otoritas terkait telah memberikan kebijakan untuk memitigasi dampak ini melalui pemberian restrukturisasi kredit. Penelitian ini bertujuan untuk memahami pengelolaan piutang murabahah sebelum pandemi, kebijakan restrukturisasi kredit saat pandemi dan pengaruh kebijakan restrukturisasi ketika pandemi tersebut pada pelaporan keuangan Bank XYZ. Dengan menggunakan pendekatan kualitatif melalui wawancara semi-struktur dan studi dokumen-dokumen terkait, didapati bahwa kebijakan restrukturisasi akibat Covid-19 ini berpengaruh terhadap penurunan rasio perputaran piutang dan ROA serta kenaikan umur rata-rata piutang dan rasio piutang non-performing.
\end{abstract}

Kata Kunci : Pandemi Covid-19, piutang murabahah, restrukturisasi kredit

\section{PENDAHULUAN}

Pandemi Coronavirus Disease 2019 (Covid-19) telah memberi dampak pada berbagai aspek kehidupan. Selain berdampak pada sektor kesehatan, Pandemi Covid-19 juga berpengaruh terhadap sektor ekonomi termasuk industri perbankan (Sukerta et al., 2021). Dampak ini antara lain berupa potensi penurunan likuiditas dan solvabilitas industri perbankan yang pada gilirannya dapat menghambat laju perekonomian nasional.

Dalam menghadapi guncangan pada sektor ekonomi dimaksud, Pemerintah memberikan respon kebijakan untuk mengatasi potensi negatif dari guncangan tersebut. Pemerintah, dalam hal ini melalui Kementerian Keuangan, Bank Indonesia, serta Otoritas Jasa Keuangan $(\mathrm{OJK})$ berwenang mengontrol stabilitas keuangan negara dengan mengeluarkan berbagai kebijakan relevan guna menstabilkan perekonomian nasional serta mengantisipasi kemungkinan kemunculan krisis ekonomi.

Terkait dengan piutang industri perbankan, Pemerintah melalui OJK menerbitkan peraturan terkait kebijakan counter-cyclical sebagai bentuk respon pemerintah dalam menanggulangi dampak Pandemi Covid-19 bagi lembaga keuangan perbankan sebagaimana diatur di dalam Peraturan OJK Nomor 11/POJK.03/2020. Aturan tersebut berisi beberapa kebijakan terkait relaksasi bagi debitur yang terkena dampak Pandemi Covid-19, penyesuaian pengaturan prinsip kehati-hatian bagi bank dalam menerapkan kebijakan tersebut, penerapan manajemen risiko, serta kebijakan terkait dengan likuiditas dan permodalan bank.

Pemerintah dalam hal ini OJK juga telah meluncurkan beberapa kebijakan relaksasi yang dikhususkan bagi industri perbankan syariah. Transaksi restrukturisasi pembiayaan murabahah menjadi salah satu produk kebijakan pemerintah yang ditujukan bagi pihak yang 


\section{JURNALKU}

Volume 1 No. 3, September 2021

terdampak pandemi. Restrukturisasi pembiayaan murabahah diberikan dengan melakukan penjadwalan ulang, memberi pemotongan sisa tagihan, atau mengonversi akad murabahah. Namun, peraturan OJK tersebut tidak bersifat mandatori artinya kebijakan relaksasi kredit dikembalikan kepada masing-masing manajemen perbankan. Dalam hal kebijakan tersebut diterapkan, maka dapat memengaruhi laporan keuangan lembaga keuangan syariah yang bersangkutan karena beberapa penyesuaian sebagai akibat kebijakan dimaksud.

Bank XYZ merupakan salah satu perusahaan di industri jasa keuangan perbankan yang melaksanakan transaksi berdasarkan prinsip dasar syariah dalam bentuk bagi hasil, jual-beli, ataupun sewa-menyewa. Sebagai perusahaan jasa keuangan yang antara lain memberikan pinjaman pada nasabah, maka proporsi terbesar yang disajikan pada laporan keuangan adalah pos terkait aset keuangan. Berdasarkan Laporan Keuangan Tahun 2019 dan 2020, Bank XYZ menyajikan porsi jumlah piutang yang relatif besar. Secara umum, jenis-jenis piutang yang dimiliki oleh Bank XYZ terdiri atas piutang murabahah, piutang istishna, dan piutang ijarah.

Setiawati (2021) menyampaikan bahwa bank syariah memberikan restrukturisasi kredit kepada nasabah yang terdampak Pandemi Covid-19 berdasarkan kebijakan restrukturisasi masing-masing bank yang mempertimbangkan hasil identifikasi bank-bank tersebut atas nasabah masing-masing. Terkait ini, salah satu cabang Bank Syariah Indonesia menerapkan beberapa strategi dalam penanganan pembiayaan murabahah yang bermasalah pada masa Pandemi Covid-19 yaitu dengan melakukan pendekatan kepada nasabah, penagihan secara intensif, pemberian surat peringatan (SP) yaitu SP 1 s.d. 3, dan restrukturisasi dengan penjadwalan ulang yaitu memperpanjang jangka waktu pembiayaan, perpanjangan jangka waktu angsuran, dan yang paling banyak digunakan di masa Pandemi covid-19 ini adalah pengurangan jumlah angsuran (Azwar, 2021).

Dampak Pandemi Covid-19 memang berpotensi meningkatkan pinjaman bermasalah sehingga dibutuhkan kesigapan perbankan dalam menangani dampak negatif agar proses bisnis tetap berjalan sesuai dengan prinsip kesinambungan (going concern). Sehubungan dengan hal tersebut, studi ini bertujuan untuk: (1) memahami pengelolaan piutang Bank XYZ sebelum Pandemi Covid-19; (2) mengetahui kebijakan restrukturisasi kredit Bank XYZ ketika Pandemi Covid-19 berlangsung; dan (3) mengetahui pengaruh kebijakan restrukturisasi kredit akibat Pandemi Covid-19 di atas terhadap pelaporan keuangan Bank XYZ.

\section{KAJIAN PUSTAKA}

Pengelolaan piutang yang efektif merupakan salah satu upaya yang dilakukan oleh perusahaan untuk mendapatkan keuntungan. Pengelolaan piutang yang efektif dapat digambarkan melalui peningkatan rasio perputaran piutang periodik sesuai dengan target yang diharapkan oleh perusahaan dan selanjutnya akan mempengaruhi perolehan profitabilitas (Surono et al., 2015).

Pandemi Covid-19 telah memberikan dampak negatif bukan hanya terhadap sektor kesehatan, tetapi juga terhadap banyak sektor dalam perekonomian. Sektor perbankan menjadi salah satu yang terkena dampak dari pandemi ini. Salah satu kebijakan untuk memitigasi dampak di sektor perbankan adalah melalui pemberian restrukturisasi kredit atas piutang nasabah/debitur. Restrukturisasi kredit bertujuan untuk memberikan keringanan bagi debitur dalam memenuhi kewajibannya. Kemudian aturan mengenai restrukturisasi dalam PJOK terkait nantinya akan jadi acuan bagi bank untuk memberikan keringanan bagi debitur yang terdampak Covid-19 (Sukerta et al., 2021).

Sari et al. (2020) menunjukkan bahwa proses restrukturisasi kredit menyelamatkan kredit macet dan menghindarkan bank dari kerugian. Restrukturisasi kredit dalam hal ini dilakukan melalui penundaan dan mengubah jumlah cicilan, bukan berdasarkan penurunan suku bunga kredit, perpanjangan jangka waktu kredit, pengurangan tunggakan bunga kredit, 


\section{JURNALKU}

Volume 1 No. 3, September 2021

pengurangan tunggakan pokok kredit, penambahan fasilitas kredit, dan/atau konversi kredit menjadi penyertaan modal sementara.

Berdasarkan kajian atas 45 emiten perbankan di Bursa Efek Indonesia, diketahui bahwa variabel restrukturisasi kredit secara parsial berpengaruh negatif terhadap variabel pendapatan. Hal ini berarti bahwa semakin tinggi restrukturisasi kredit maka akan semakin rendah jumlah pendapatan perusahaan perbankan yang terdaftar di BEI (Septriawan et al., 2021). Penyelesaian pembiayaan macet pada pembiayaan jual beli angsuran di BMT IKPM dapat dilakukan dengan cara negosiasi yang bersifat kekeluargaan untuk menyelesaikan perselisihan pembiayaan macet pada restrukturisasi (Retnowati et al., 2021)

Dengan menggunakan metode deskriptif komparatif dan pendektan kuantitatif, Puspita et al. (2020) menghitung rasio likuiditas berdasarkan laporan keuangan yang diambil yaitu Triwulan III 2019 sebelum pandemi muncul dan laporan keuangan Triwulan III 2020 saat pandemi terjadi. Rata-rata perusahaan perbankan masih memiliki kemampuan untuk memenuhi kewajibannya pada saat pandemi meskipun bila restrukturisasi kredit diperpanjang (Puspita et al., 2020).

Hambatan dalam penyelesaian pembiayaan Bank Muamalat Kantor Cabang Madiun terjadi karena masalah verifikasi berkas administrasi yang harus dipenuhi oleh nasabah. Adapun strategi dalam penyelesaian pembiayaan Bank Muamalat Kantor Cabang Madiun menggunakan restrukturisasi kredit melalui: penjadwalan kembali (rescheduling), persyaratan kembali (reconditioning), dan penataan kembali (restructuring)(Setiawan \& Ali, 2021).

\section{METODE}

Studi ini menggunakan metode kualitatif. Metode ini merupakan jenis penelitian yang temuannya tidak diperoleh melalui prosedur statistik atau bentuk hitungan lainnya. Meskipun datanya dapat dihitung dan disampaikan dalam angka-angka sebagaimana dalam sensus, analisis datanya bersifat kualitatif (Strauss dan Corbin, 2007:1). Adapun pendekatan yang digunakan dalam studi ini adalah pendekatan studi kasus melalui wawancara semi-struktur kepada informan yang merupakan pegawai terkait fungsi akuntansi Bank XYZ dan juga studi atas dokumen-dokumen yang relevan. Studi kasus merupakan salah satu jenis pendekatan kualitatif yang menelaah sebuah kasus tertentu dalam konteks atau latar kehidupan nyata kontemporer (Irawan \& Erdika, 2021).

\section{HASIL DAN PEMBAHASAN}

\section{Pengelolaan Piutang Bank XYZ Tahun 2019}

Piutang diakui pada saat tanggal penyerahan aset dalam rangka melaksanakan perjanjian yang telah disepakati dengan debitur. Pada saat pengakuan awal, piutang diakui pada nilai wajarnya ditambah dengan biaya transaksi. Selanjutnya, piutang akan diukur berdasarkan biaya perolehan yang diamortisasi dengan menggunakan metode imbal hasil efektif dikurangi cadangan kerugian penurunan nilai atas piutang dan margin yang ditangguhkan yang dapat direalisasikan. Pendapatan margin yang diperoleh dari piutang dicatat dalam laporan laba rugi dan dilaporkan sebagai "Pendapatan dari jual beli".

Piutang murabahah dikategorikan sebagai aset keuangan dalam kelompok pinjaman yang diberikan dan piutang sesuai PSAK 55 tentang Pengakuan dan Pengukuran atas Instrumen Keuangan. Dalam hal jika terjadi penurunan nilai terhadap suatu piutang, kerugian penurunan nilai dilaporkan sebagai pengurang dari nilai tercatat dari piutang, serta diakui di dalam laporan laba rugi sebagai Cadangan Kerugian Penurunan Nilai (CKPN) atas aset keuangan.

Bank XYZ dalam menilai CKPN atas piutang dihitung secara individual dan kolektif. Dalam penghitungan CKPN individual untuk piutang murabahah, Bank mengikuti peraturan yang sudah ditetapkan di PSAK 102 tentang Akuntansi Murabahah dan ketentuan di PSAK 55 


\section{JURNALKU}

Volume 1 No. 3, September 2021

tentang Instrumen Keuangan: Pengakuan dan Pengukuran dengan menerapkan konsep one obligor. Bank XYZ mengevaluasi penurunan nilai piutang disertai dengan bukti objektif sebagai akibat dari peristiwa merugikan yang terjadi setelah pengakuan awal piutang tersebut yang berdampak pada estimasi cash flow masa mendatang atas piutang yang sudah diestimasi secara andal.

Bank membentuk CKPN atas piutang murabahah dihitung secara individual, jika memenuhi salah satu syarat berikut: (1) Piutang murabahah yang memiliki kolektibilitas kurang lancar, diragukan, dan macet yang memiliki saldo piutang secara individual di atas Rp10 miliar; atau (2) Piutang murabahah yang telah direstrukturisasi dan memiliki saldo nilai piutang yang secara individual di atas Rp10 miliar.

Bukti objektif penurunan nilai atas piutang dapat berupa terjadinya peristiwa yang merugikan yang memiliki dampak pada estimasi cash flow di masa mendatang melingkupi: (1) adanya indikasi masalah keuangan secara signifikan yang dialami oleh debitur atau pihak yang melakukan pinjaman; (2) pelanggaran kontrak, seperti tunggakan pembayaran pokok atau wanprestasi atau margin pembiayaan; (3) restrukturisasi dengan beberapa persyaratan yang diberikan kepada debitur yang memang benar-benar mengalami masalah keuangan; (4) kemungkinan debitur atau pihak yang meminjam kepada bank akan dinyatakan pailit atau melakukan reorganisasi keuangan lainnya; (5) hilangnya pasar aktif dari aset keuangan akibat kesulitan keuangan; dan (6) Data yang diamati mengindikasikan terdapat penurunan yang dapat diukur atas estimasi cash flow di masa yang akan datang.

Piutang murabahah yang secara individual nilainya di bawah Rp10 miliar serta nilai piutang di atas Rp10 miliar dengan kolektibilitas lancar atau dalam perhatian khusus dan tidak direstrukturisasi, makan pembentukan CKPN dihitung secara kolektif. Perhitungan CKPN atas piutang murabahah yang dinilai secara kolektif mengikuti peraturan PSAK 55 tentang Instrumen Keuangan: Pengakuan dan Pengukuran.

Jika Bank XYZ tidak mendapatkan bukti objektif terkait penurunan nilai atas piutang yang dinilai secara individual, maka penurunan nilai piutang tersebut dilakukan secara kolektif. Piutang yang dinilai secara kolektif dikelompokkan berdasarkan kesamaan karakteristik risiko kredit dalam mengevaluasi penurunan nilai, misalnya dengan mempertimbangkan segmentasi kredit dan status tunggakan. Karakteristik yang dipilih menunjukkan kemampuan debitur untuk membayar seluruh kewajiban yang telah jatuh tempo sesuai persyaratan kontrak dan harus relevan dengan estimasi cash flow di masa mendatang dari kelompok piutang tersebut. Bank XYZ mengategorikan piutangnya berdasarkan kesamaan karakteristik risiko kredit atau kolektibilitasnya. Piutang dalam hal ini dikelompokkan ke dalam 5 (lima) kategori yaitu piutang lancar, dalam perhatian khusus, kurang lancar, diragukan, dan macet.

Piutang lancar digolongkan kepada debitur yang selalu melunasi kewajibannya secara lancar dan tidak pernah melakukan penunggakan secara berturut-turut selama tiga bulan. Piutang kurang lancar digolongkan kepada debitur yang selama tiga bulan atau sembilan puluh hari berturut-turut kewajibannya tidak dilunasi. Piutang diragukan dikategorikan bagi debitur yang memiliki tunggakan pembayaran kewajiban dan margin yang telah melewati enam bulan atau 180 hari s.d. sembilan bulan atau 270 hari. Sedangkan debitur yang memiliki agunan yang telah disita oleh bank tetapi masih belum cukup melunasi semua kewajibannya digolongkan sebagai piutang macet. Di dalam Catatan atas Laporan Keuangan, Bank XYZ juga mengungkapkan piutang dalam beberapa klasifikasi yaitu piutang berdasarkan jenis dan mata uang, sektor ekonomi, jangka waktu dan sisa umur jatuh tempo piutang, dan diklasifikasikan berdasarkan pihak.

Jika penurunan nilai suatu kelompok piutang dinilai secara kolektif, arus kas masa mendatang diestimasi berdasarkan kerugian di masa lalu yang pernah dialami atas piutang yang memiliki karakteristik risiko kredit yang sejenis dengan karakteristik risiko kredit kelompok 


\section{JURNALKU}

Volume 1 No. 3, September 2021

tersebut di dalam Bank XYZ. Kerugian yang sudah dialami pada tahun sebelumnya, disesuaikan berdasarkan data terkini yang dapat diobservasi untuk menunjukkan tidak adanya pengaruh antara kondisi saat ini yang dengan tahun saat terjadinya kerugian. Hal tersebut juga digunakan untuk menghapus pengaruh kondisi yang ada pada tahun sebelumnya namun sudah tidak ada lagi saat ini.

Bank XYZ menggunakan metode statistical model analysis atau migration analysis untuk menghitung penurunan nilai piutang secara kolektif, yaitu dengan mengamati pergerakan piutang pada tiap kategori yang dibentuk. Bank akan menghitung probabilitas nilai tak tertagih suatu piutang dan bermigrasi pada periode selanjutnya. Bank XYZ menghitung penurunan nilai atas piutang secara kolektif berdasarkan data historis selama tiga tahun.

Jumlah kerugian piutang yang dibentuk melalui akun CKPN dicatat dan diakui pada laporan laba rugi. Pendapatan margin tetap diakui atas nilai tercatat yang sudah diturunkan tersebut sesuai dengan tingkat imbal hasil efektif awal yang digunakan untuk mendiskonto arus kas masa mendatang dari piutang tersebut. Apabila pada tahun berikutnya peristiwa merugikan yang terjadi setelah pengakuan kerugian penurunan nilai mengakibatkan jumlah estimasi penyisihan kerugian mengalami kenaikan atau penurunan maka kerugian penurunan nilai yang sudah diakui sebelumnya dinaikkan atau diturunkan dengan menyesuaikan akun CKPN.

Bank XYZ melakukan penghentian pengakuan piutang ketika hak kontraktual atas arus kas yang berasal dari piutang tersebut berakhir. Selain itu, penghentian pengakuannya juga dilakukan ketika piutang tersebut telah dialihkan dan secara substansial seluruh manfaat serta risiko atas kepemilikan piutang tersebut telah ditransfer.

Apabila secara substansial seluruh manfaat dan risiko tidak ditransfer, Bank XYZ melakukan evaluasi dalam rangka memastikan apakah terdapat pengaruh berkelanjutan atas kendali yang dimiliki yang tidak mencegah penghentian pengakuan. Pihak bank dalam hal ini harus mengelola risiko kredit dengan baik dan efektif untuk meminimalisasi kemungkinan terjadinya kegagalan bayar oleh debitur sehingga tidak berdampak pada kemampuan likuiditas, permodalan, dan profitabilitas bank.

Strategi yang dilakukan oleh Bank XYZ dalam hal pengelolaan risiko kredit adalah memperbarui Standard Operating Procedure (SOP) bisnis masing-masing produk pembiayaan, menjaga konsentrasi portofolio pembiayaan, menerapkan scoring dan watchlist tools, memperbaiki kualitas pembiayaan dengan early restructuring dan monitoring, menangani pembiayaan bermasalah dengan pembinaan dan restrukturisasi, serta melakukan stress test portofolio.

\section{Kebijakan Restrukturisasi Kredit BANK XYZ pada Tahun 2020}

Dewan Standar Akuntansi Syariah Ikatan Akuntan Indonesia (DSAS-IAI) telah menegaskan pada saat siaran pers bahwa PSAK 71 tidak diterapkan pada perusahaan atau transaksi yang berbasis syariah. Khusus untuk penurunan nilai piutang murabahah, ISAK 102 tentang Penurunan Nilai Piutang Murabahah merupakan bridging standard untuk mengisi kekosongan peraturan terkait penurunan nilai bagi aset yang bersumber dari transaksi syariah. ISAK 102 ini memandu bank untuk tetap menerapkan kebijakan akuntansi terkait pembentukan penurunan nilai piutang murabahah dengan menggunakan kebijakan sebelumnya, seperti regulatory provisioning, incurred loss, atau pendekatan lain yang dapat menghasilkan informasi relevan dan andal. Bank XYZ dalam hal ini menggunakan incurred loss model dalam menghitung penurunan nilai piutang murabahah dalam penyusunan laporan keuangan tahun 2020 (Yakub \& Firdaus, 2020).

Berdasarkan siaran pers IAI atas dampak Pandemi Covid-19 terhadap penerapan ISAK 102 tentang Penurunan Nilai Piutang Murabahah, entitas yang menggunakan pendekatan incurred loss harus mengikuti pertimbangan profesional saat mengevaluasi dampak Pandemi Covid-19 dalam menentukan berapa jumlah penurunan nilai atas piutang murabahah. DSAS- 


\section{JURNALKU}

Volume 1 No. 3, September 2021

IAI memberikan petunjuk terkait penerapan incurred loss model agar meminimalkan keragaman dalam praktik yang disebabkan oleh pertimbangan profesional tiap entitas dengan mengevaluasi apakah terdapat bukti objektif yang menunjukkan bahwa piutang mengalami penurunan nilai sebagai akibat dari peristiwa merugikan yang terjadi setelah pengakuan awal. Hal tersebut dapat berdampak pada estimasi arus kas masa mendatang sehingga laporan keuangan yang dihasilkan tetap dapat diperbandingkan untuk tujuan umum.

Berdasarkan pada pertimbangan bahwa dampak yang muncul dari Covid-19 diprediksi bersifat sementara dan memiliki tingkat ketidakpastian yang tinggi, pengungkapan yang memadai sangat diperlukan agar dapat memberikan transparansi bagi para pengguna laporan keuangan. Oleh sebab itu, entitas perlu melakukan pengungkapan atas dampak dari penerapan kebijakan stimulus perekonomian yang telah diterapkan serta risiko yang muncul dan bagaimana entitas mengelola risiko tersebut.

Pengelolaan risiko kredit yang dilakukan oleh Bank XYZ pada tahun 2020 kurang lebih sama seperti yang dilakukan pada tahun sebelumnya, namun terdapat beberapa langkah penyesuaian yang diambil Bank XYZ dalam mengatasi dampak dari Pandemi Covid-19 sebagai berikut: (1) Menetapkan in-house limit Batas Maksimum Penyediaan Dana (BMPD) sebagai batas persentase maksimum penyediaan dana bank umum syariah yang diperbolehkan, credit line, dan kewenangan pemutusan pembiayaan; dan (2) Menetapkan jangka waktu pembiayaan dengan mempertimbangkan jenis pembiayaan, potensi risiko, likuiditas, dan imbal hasil.

Di dalam Catatan atas Laporan Keuangan tahun 2020, Bank XYZ telah menjelaskan pengelolaan risiko yang dikhususkan atas restrukturisasi akibat Covid-19 dengan melakukan beberapa mitigasi yaitu sebagai berikut. Pertama, Bank XYZ telah membentuk tim task force pada tanggal 31 Maret 2020 untuk menetapkan strategi untuk mengatasi pembiayaan yang berpotensi macet serta mengawasi dan mengevaluasi strategi yang telah dibuat dalam mengatasi kredit bermasalah. Selain itu, Bank XYZ membentuk program dalam upaya percepatan penanganan nasabah yang terdampak Covid-19. Kedua, Bank XYZ menentukan sektor dan kriteria nasabah terdampak Covid-19 yang boleh direstrukturisasi kredit sesuai dengan hasil stress test terkait. Ketiga, Bank XYZ menyiapkan skema restrukturisasi kredit dengan melakukan penundaan pembayaran tanpa adanya potongan bagi debitur yang terdampak Covid19. Keempat, secara proaktif, Bank XYZ akan menangani pembayaran pinjaman yang bermasalah dan menawarkan kepada nasabah jika ada kondisi makro ekonomi yang dapat menurunkan kemampuan nasabah dalam melunasi kewajiban, tentu dengan tetap memperhatikan kondisi nasabah. Kelima, Bank XYZ melakukan penyaluran pembiayaan dengan tetap menerapkan prinsip kehati-hatian yang diberikan secara selektif. Terakhir, Bank XYZ menambah strategi untuk mengupayakan penagihan dan penyelesaian pembiayaan bermasalah.

Dalam kondisi normal, restrukturisasi atau penjadwalan ulang pinjaman mensyaratkan keberadaan bukti objektif terkait penurunan nilai atas pinjaman yang mencerminkan bahwa kondisi keuangan debitur kurang begitu baik. Kondisi Pandemi Covid-19 telah memberikan dampak terhadap seluruh sektor kehidupan, halmana Bank XYZ mempertimbangkan bahwa restrukturisasi pembiayaan atas nasabah yang terdampak Covid-19 tidak secara otomatis memicu peningkatan risiko kredit yang substansial. Hal ini sesuai dengan peraturan Otoritas Jasa Keuangan dan Ikatan Akuntan Indonesia, yaitu POJK Nomor 11 /POJK.03/2020 tentang kebijakan countercyclical sebagai panduan bagi bank dalam menghadapi dampak dari bencana Pandemi Covid-19. Dalam peraturan ini dinyatakan bahwa kualitas kredit atau pinjaman yang direstrukturisasi ditetapkan lancar sejak dilakukan restrukturisasi (Prabowo, 2020).

Jika debitur telah memenuhi kriteria sesuai dengan POJK No. 11/POJK.03/2020, maka kualitas pinjaman restrukturisasi Covid-19 tetap dikelompokkan sebagai piutang dengan kualitas lancar atau kualitas dalam perhatian khusus. Berdasarkan ketentuan tersebut, kerugian 


\section{JURNALKU}

Volume 1 No. 3, September 2021

atas perbedaan nilai kini dengan estimasi arus kas debitur yang terjadi akibat restrukturisasi Covid-19 (grace period 3 - 12 bulan) tidak diakui oleh Bank XYZ.

Untuk mengatasi dampak yang ditimbulkan dari Pandemi Covid-19, Bank XYZ melakukan evaluasi dalam memperhitungkan penyisihan kerugian penurunan nilai pinjaman. Bank XYZ melakukan Langkah-langkah penyesuaian untuk memastikan nilai CKPN atas pinjaman yang dicatat di laporan keuangan dapat diandalkan, mengingat bahwa metode perhitungan penyisihan kerugian tidak sepenuhnya dapat mencerminkan estimasi kerugian yang akurat di saat kondisi yang tidak normal akibat Pandemi Covid-19.

Penyesuaian yang dilakukan oleh Bank XYZ terkait penyisihan piutang adalah mengatur kebijakan overlay atau membentuk tambahan CKPN yang dihitung secara kolektif untuk restrukturisasi Covid-19 baik pada segmen wholesale dan ritel melalui penyesuaian faktor Probability of Default (PD), yaitu tingkat probabilitas pihak peminjam yang tidak dapat melunasi kewajibannya. Aturan yang disesuaikan terkait hal ini adalah: (1) PD ditetapkan per rekening atau nasabah sesuai dengan tingkatan risiko (low, medium, high); (2) penetapan tingkatan risiko pada masing-masing rekening atau nasabah akan berakibat pada kenaikan jumlah CKPN dengan menggunakan konsep penurunan kualitas satu atau dua tingkat lebih buruk dari standar CKPN saat ini.

Berdasarkan POJK No. 11/POJK.03/2020, apabila nasabah tidak mampu menyelesaikan kewajiban pada saat pandemi maka pihak bank dapat memberikan keringanan berupa restrukturisasi kredit. Restrukturisasi kredit merupakan upaya yang dilakukan bank untuk membantu nasabah dalam menyelesaikan kewajiban. Restrukturisasi piutang Bank XYZ dapat dilakukan dengan penjadwalan kembali, perpanjangan waktu, dan penambahan fasilitas piutang bagi nasabah.

Penjadwalan kembali atau rescheduling merupakan upaya bank yang dilakukan bagi nasabah yang masih memiliki itikad baik namun tidak mampu untuk membayar kewajibannya dengan membuat penjadwalan kembali. Alternatif penjadwalan kembali yang dapat dilakukan bank adalah perpanjangan waktu kredit atau jadwal angsuran bulanan yang diubah menjadi triwulan. Berikut adalah ketentuan lain yang harus dipenuhi nasabah agar pinjaman mereka dapat di-rescheduling: (1) prospek usaha yang dimiliki nasabah masih baik dan kemungkinan dapat memenuhi kewajibannya kembali setelah dilakukan rescheduling; (2) tidak menambah jumlah tagihan yang tersisa; (3) beban biaya yang timbul dalam proses rescheduling merupakan biaya riil; dan (4) proses rescheduling harus berdasarkan kesepakatan kedua pihak.

Restrukturisasi dapat pula dilakukan dengan mengubah struktur pinjaman yang mendasari pemberian kredit atau modifikasi persyaratan pembayaran. Bank XYZ tidak mencatat dampak restrukturisasi atas pinjaman secara prospektif sehingga nilai pinjaman yang tercatat pada tanggal restrukturisasi tidak diubah. Akan tetapi, nilai pengurangan tersebut diakui sebagai pengurang pendapatan murabahah pada tahun berjalan apabila nilai tercatat sebelum restrukturisasi lebih tinggi daripada jumlah piutang setelah dikurangi keuntungan baru yang ditentukan setelah restrukturisasi. Pendapatan margin setelah direstrukturisasi dalam hal ini diakui sejumlah besaran margin yang telah disepakati dalam struktur pinjaman baru.

Kriteria sektor yang dapat direstrukturisasi adalah sebagai berikut: (1) sektor yang terdampak langsung, antara lain pertanian, kehutanan, perikanan, hotel dan restoran, jasa pariwisata dan penunjang (termasuk umroh, biro perjalanan dan transportasi), serta jasa logistik; (2) sektor terkait ekspor dan impor, antara lain kelapa sawit, migas, peralatan elektronik, batu bara, industri kimia dan farmasi, industri mesin dan suku cadang, industri alat angkutan, tekstil dan pakaian jadi, serta industri karet dan plastik; dan (3) sektor lain yang ditetapkan kemudian oleh bank sebagai sektor terdampak.

Adapun kriteria nasabah terdampak Pandemi Covid-19 dapat direstrukturisasi adalah sebagai berikut: (1) nasabah yang memiliki bidang usaha atau tempat mereka bekerja termasuk 


\section{JURNALKU}

Volume 1 No. 3, September 2021

ke dalam sektor terdampak (termasuk nasabah fasilitas pembiayaan koperasi karyawan); (2) nasabah memiliki hubungan bisnis, grup usaha, atau mempekerjakan tenaga dari dan dengan Tiongkok atau negara lain yang terdampak Covid-19; dan (3) termasuk kriteria yang ditetapkan kemudian oleh bank menjadi nasabah terdampak.

Bank XYZ mengklasifikasikan kondisi nasabah yang terdampak Pandemi Covid-19 pada beberapa tingkatan yaitu ringan, sedang, dan berat. Bagi nasabah perorangan golongan berpenghasilan tetap (golbertap) yaitu perusahaan/nasabah yang terkena dampak Covid-19 sehingga berpengaruh pada penghasilan gaji/nasabah dianggap memiliki dampak dengan kondisi tingkat ringan apabila gaji dan tunjangan turun s.d. 30\%; tingkat sedang jika gaji dan tunjangan turun di atas $30 \%$ s.d. $70 \%$; serta dikategorikan berat jika gaji dan tunjangan turun lebih dari 70\% atau di-PHK/dirumahkan/positif Covid-19 sehingga tidak menerima gaji sama sekali.

Bagi nasabah yang tergolong badan usaha dan perorangan non-golbertap seperti wiraswasta, memiliki dampak dengan tingkatan ringan apabila penurunan omset s.d. 30\%; tingkat sedang jika penurunan omset di atas 30\% s.d. $70 \%$; dan apabila usaha nasabah sudah tutup atau penurunan omset sudah lebih dari $70 \%$ termasuk ke dalam nasabah yang terdampak dengan tingkat berat.

\section{Pengaruh Kebijakan Restrukturisasi Kredit akibat Pandemi Covid-19 terhadap Pelaporan Keuangan Bank XYZ}

Berdasarkan Laporan Keuangan Bank XYZ, nilai bersih piutang dari tahun 2019 ke tahun 2020 mengalami kenaikan sebesar Rp4.980.265 juta. Hal ini diikuti dengan kenaikan cadangan kerugian penurunan nilai dan penyisihan kerugian sebesar Rp703.294 juta. Jenis piutang yang paling besar disajikan pada tahun 2019 dan 2020 adalah piutang murabahah yang secara porsi hampir mendekati $100 \%$ dari seluruh piutang perusahaan.

Penyesuaian kebijakan akibat Pandemi Covid-19 yang diterapkan oleh Bank XYZ berpengaruh pada penyajian piutang di laporan keuangan. Salah satu penyesuaian yang paling berpengaruh adalah kebijakan overlay atau pembentukan tambahan CKPN yang dihitung secara kolektif untuk restrukturisasi Covid-19. Kebijakan ini berdampak pada penyajian dan perhitungan estimasi pencadangan kerugian penurunan nilai atas piutang.

Jumlah piutang Bank XYZ yang direstrukturisasi akibat Pandemi Covid-19 per tanggal 31 Desember 2020 adalah sebesar Rp4.178.390 juta dari total piutang Rp5.711.395 juta. Data piutang restrukturisasi akibat Covid-19 diklasifikasikan menjadi tiga kategori berdasarkan kolektibilitasnya yaitu lancar, dalam perhatian khusus, dan non-performing financing yang masing-masing dirinci lagi atas segmen wholesale dan ritel. Pada tahun 2020, jumlah piutang yang direstrukturisasi mengalami kenaikan yang sangat signifikan dibandingkan tahun sebelumnya yang hanya sebesar Rp1.249.007 juta.

Bank XYZ memperhitungkan tambahan penyisihan kerugian penurunan nilai piutang yang direstrukturisasi sebagai kebijakan yang diambil atas dampak dari Pandemi Covid-19. Bank melakukan penyesuaian faktor Probability of Default (PD) atau probabilitas kebangkrutan atas pinjaman restrukturisasi Covid-19 sesuai analisis risiko kepada masingmasing nasabah yang terdampak Covid-19. Untuk restrukturisasi piutang murabahah akibat Covid-19, Bank XYZ telah menyisihkan tambahan kerugian penurunan nilai sebesar Rp514.702 juta yang berasal dari segmen wholesale dan ritel.

Bank XYZ menghitung cadangan kerugian penurunan nilai atas piutang secara kolektif dengan melihat beberapa aspek seperti segmentasi dan kualitas piutang. Dalam membentuk estimasi cadangan atas piutang, Bank XYZ membuat dugaan untuk menentukan kerugian yang terikat dan menentukan kriteria input yang diperlukan berdasarkan data historis dan kondisi ekonomi terkait. Keakuratan dalam mengestimasi pencadangan bergantung pada seberapa baik estimasi cash flow di masa mendatang untuk cadangan counterparty tertentu dan asumsi model 


\section{JURNALKU}

Volume 1 No. 3, September 2021

serta kriteria yang digunakan dalam menentukan cadangan kolektif. Setiap kelompok perlu dilakukan analisis secara terpisah karena probabilitas penurunan nilai tiap kelompok berbeda. Pada tahun 2020, alokasi CKPN atas piutang Bank XYZ mengalami kenaikan secara signifikan pada tiap kategori dibandingkan dengan tahun-tahun sebelumnya.

Tabel 1. Alokasi CKPN per Kategori Piutang tahun 2018-2020 (dalam jutaan)

\begin{tabular}{|c|l|r|r|r|r|r|r|}
\hline \multicolumn{2}{|c|}{} & \multicolumn{1}{c|}{ Lancar } & \multicolumn{1}{c|}{ DPK } & Kurang lancar & Diragukan & \multicolumn{1}{c|}{ Macet } & \multicolumn{1}{c|}{ Jumlah } \\
\hline \multirow{3}{*}{2020} & Total piutang (bruto) & 43.403 .148 & 1.462 .293 & 301.331 & 138.977 & 549.918 & 45.855 .667 \\
\cline { 2 - 8 } & CKPN & $(651.077)$ & $(371.633)$ & $(173.426)$ & $(89.530)$ & $(486.812)$ & $(1.772 .478)$ \\
\cline { 2 - 8 } & Total piutang (neto) & 42.752 .071 & 1.090 .660 & 127.905 & 49.447 & 63.106 & 44.083 .189 \\
\cline { 2 - 8 } & $\%$ CKPN & $1,50 \%$ & $25,41 \%$ & $57,55 \%$ & $64,42 \%$ & $88,52 \%$ & $3,87 \%$ \\
\hline \multirow{4}{*}{2019} & Total piutang (bruto) & 38.460 .420 & 805.197 & 598.186 & 90.560 & 217.745 & 40.172 .108 \\
\cline { 2 - 8 } & CKPN & $(429.360)$ & $(123.753)$ & $(305.382)$ & $(40.816)$ & $(169.873)$ & $(1.069 .184)$ \\
\cline { 2 - 8 } & Total piutang (neto) & 38.031 .060 & 681.444 & 292.804 & 49.744 & 47.872 & 39.102 .924 \\
\cline { 2 - 8 } & $\%$ CKPN & $1,12 \%$ & $15,37 \%$ & $51,05 \%$ & $45,07 \%$ & $78,01 \%$ & $2,66 \%$ \\
\hline \multirow{3}{*}{2018} & Total piutang (bruto) & 35.746 .106 & 1.411 .905 & 282.561 & 242.986 & 673.200 & 38.356 .758 \\
\cline { 2 - 8 } & CKPN & $(490.478)$ & $(256.984)$ & $(76.345)$ & $(141.765)$ & $(383.711)$ & $(1.349 .283)$ \\
\cline { 2 - 8 } & Total piutang (neto) & 35.255 .628 & 1.154 .921 & 206.216 & 101.221 & 289.489 & 37.007 .475 \\
\cline { 2 - 8 } & $\%$ CKPN & $1,37 \%$ & $18,20 \%$ & $27,02 \%$ & $58,34 \%$ & $57,00 \%$ & $3,52 \%$ \\
\hline
\end{tabular}

Sumber: Hasil Olahan Penulis (2021)

Kebijakan overlay yang diterapkan saat terjadi Pandemi Covid-19 ini memerlukan penilaian kinerja atas pengelolaan piutang yang dimiliki Bank XYZ antara lain dengan menggunakan rasio piutang non-performing. Rasio ini memberikan gambaran sejauh mana bank dapat mengatasi masalah risiko kredit secara tepat sehingga tidak berdampak negatif bagi pihak bank sendiri. Semakin besar rasio piutang non-performing, maka semakin besar cadangan yang harus dibentuk dan semakin besar juga opportunity cost yang harus ditanggung. Rasio piutang non-performing merupakan perbandingan antara total piutang bermasalah dengan total piutang sebelum dikurangi dengan penyisihan kerugian atas piutang. Piutang bermasalah merupakan piutang yang termasuk ke dalam golongan kurang lancar, yang diragukan, dan macet.

$$
\text { Rasio piutang non performing }=\frac{\text { Piutang bermasalah }}{\text { Total piutang }} \times 100 \%
$$

Dalam Tabel 2 disajikan rasio piutang non-performing Bank XYZ yang mengalami penurunan dari tahun ke tahun. Pada tahun 2020, rasio piutang non-performing menunjukkan angka $0,52 \%$ secara neto dan $2,16 \%$ secara gross. Angka ini dapat disebut cukup aman karena jauh dari ambang batas maksimal yang ditetapkan oleh OJK yaitu sebesar 5\%. Penurunan rasio piutang non-performing antara lain disebabkan karena Bank XYZ lebih menerapkan prinsip kehati-hatian dalam pemilihan nasabah untuk penyaluran pinjaman. Hal ini juga mengisyaratkan bahwa kinerja Bank XYZ dalam hal pengelolaan piutang bermasalah relatif baik.

Tabel 2. Rasio piutang non-performing Bank XYZ (dalam jutaan)

\begin{tabular}{cccc}
\hline Tahun & $\begin{array}{c}\text { Total Piutang } \\
\text { bermasalah }\end{array}$ & Total piutang & $\begin{array}{c}\text { Rasio piutang } \\
\text { non performing }\end{array}$ \\
\hline & $(\mathrm{a})$ & $(\mathrm{b})$ & $(\mathrm{a}) /(\mathrm{b}) * 100 \%$ \\
\hline 2018 (neto) & 596.926 & 38.356 .758 & $1,56 \%$ \\
2018 (gross) & 1.198 .747 & 38.356 .758 & $3,13 \%$ \\
\hline 2019 (neto) & 390.420 & 40.172 .108 & $0,97 \%$ \\
2019 (gross) & 906.491 & 40.172 .108 & $2,26 \%$ \\
\hline 2020 (neto) & 240.458 & 45.855 .667 & $0,52 \%$ \\
2020 (gross) & 990.226 & 45.855 .667 & $2,16 \%$ \\
\hline
\end{tabular}

Sumber: Hasil Olahan Penulis (2021) 


\section{JURNALKU}

Volume 1 No. 3, September 2021

Selanjutnya, hasil perhitungan rasio terkait efektivitas piutang pada Tabel 3 menunjukkan bahwa perputaran piutang Bank XYZ pada tahun 2020 mengalami penurunan yang diikuti juga dengan peningkatan umur rata-rata piutang. Kebijakan restrukturisasi akibat Pandemi Covid-19 berupa penjadwalan kembali, perpanjangan waktu, dan penambahan fasilitas piutang bagi nasabah yang diterapkan pada tahun 2020 menyebabkan waktu yang diperlukan untuk melunasi piutang menjadi lebih panjang sehingga perputaran piutang yang dihasilkan menurun.

$$
\begin{gathered}
\text { Perputaran piutang }=\frac{\text { Penjualan } / \text { Pendapatan }}{\text { Rata }- \text { rata piutang }} \\
\text { Rata }- \text { rata umur piutang }=\frac{\mathbf{3 6 0}}{\text { Perputaran piutang }}
\end{gathered}
$$

Tabel 1. Rasio Perputaran Piutang dan Umur Rata-rata Piutang

Sumber: Hasil Olahan Penulis (2021)

\begin{tabular}{lccc}
\hline & 2018 & 2019 & 2020 \\
\hline Perputaran piutang & 0,214 & 0,221 & 0,208 \\
Umur rata-rata piutang & $1.679,6$ & $1.627,5$ & $1.734,0$ \\
\hline
\end{tabular}

Tabel 4 menunjukkan bahwa selama 3 (tiga) tahun berturut-turut, jumlah aset serta laba bersih setelah pajak Bank XYZ mengalami kenaikan. Namun demikian, rasio return on asset yang mengalami kenaikan di tahun 2018 sebesar 0,62\% menjadi 1,14\% di tahun 2019 kemudian mengalami penurunan pada tahun 2020 menjadi sebesar 1,13\%. Hal ini menunjukkan bahwa kinerja Bank XYZ relatif menurun dalam menghasilkan laba berdasarkan aset yang dimiliki.

$$
\text { Return on asset }=\frac{\text { net income after tax }}{\text { Total aset }} \times 100 \%
$$

Tabel 2. Perhitungan Return on Asset (dalam jutaan)

\begin{tabular}{lccc}
\hline & 2018 & 2019 & 2020 \\
\hline Laba setelah pajak & 605.213 & 1.275 .034 & 1.434 .488 \\
Jumlah aset & 98.341 .116 & 112.291 .867 & 126.907 .940 \\
Return on Asset & $0,62 \%$ & $1,14 \%$ & $1,13 \%$ \\
\hline
\end{tabular}

Sumber: Hasil Olahan Penulis (2021)

Berdasarkan Tabel 5, persentase perubahan kenaikan total aset di tahun 2019 dan 2020 tidak berbeda jauh hanya selisih sekitar $0,9 \%$. Sementara, perubahan kenaikan laba setelah pajak di tahun 2019 mengalami kenaikan yang sangat signifikan yaitu melebihi 50\%. Hal ini mengakibatkan persentase ROA tahun 2020 menjadi lebih kecil dibandingkan dengan tahun 2019. ROA tahun 2020 jika dibandingkan dengan ROA tahun sebelumnya mengalami penurunan sekitar $0,9 \%$. Ini berarti bahwa bila diasumsikan tingkat penurunan sebesar minimal 5\% sebagaimana batas maksimal non-performing loan OJK di atas, berpengaruh terhadap pengambilan keputusan pengguna laporan keuangan, maka penurunan tersebut merupakan penurunan yang relatif tidak signifikan. Hasil ini menunjukkan bahwa Bank XYZ masih relatif dapat mempertahankan kinerja pengelolaan aset keuangan di saat pandemik, terbukti dengan perolehan laba setelah pajak dengan persentase perubahan yang jauh dari tahun sebelumnya. 
Tabel 3. Perubahan pada total aset dan laba setelah pajak (dalam jutaan)

\begin{tabular}{ccccc}
\hline Tahun & Total Aset & $\begin{array}{c}\text { Kenaikan } \\
\text { (Penurunan) } \%\end{array}$ & Laba setelah pajak & $\begin{array}{c}\text { Kenaikan } \\
\text { (Penurunan) } \%\end{array}$ \\
\hline 2018 & 98.341 .116 & - & 605.213 & - \\
2019 & 112.291 .867 & $12,4 \%$ & 1.275 .034 & $52,5 \%$ \\
2020 & 126.907 .940 & $11,5 \%$ & 1.434 .488 & $11,1 \%$ \\
\hline
\end{tabular}

Sumber: Hasil Olahan Penulis (2021)

\section{PENUTUP}

Simpulan

Restrukturisasi atau penjadwalan ulang pinjaman sebelum Pandemi Covid-19 mensyaratkan keberadaan bukti objektif terkait penurunan nilai atas pinjaman yang mencerminkan bahwa kondisi keuangan debitur kurang begitu baik. Kondisi Pandemi Covid19 telah memberikan dampak terhadap banyak sektor kehidupan, halmana Bank XYZ mempertimbangkan bahwa restrukturisasi pembiayaan atas nasabah yang terdampak Covid-19 tidak secara otomatis memicu peningkatan risiko kredit yang substansial. Kebijakan restrukturisasi akibat Covid-19 ini berpengaruh terhadap penurunan rasio perputaran piutang dan ROA serta kenaikan umur rata-rata piutang dan rasio piutang non-performing. Hal ini mengindikasikan bahwa kebijakan restrukturisasi tersebut relatif dapat menekan angka piutang yang bermasalah namun menyebabkan perputaran piutang dan umur rata-rata piutang dalam kondisi tidak baik akibat perpanjangan waktu dan penjadwalan kembali piutang nasabah yang terdampak Covid-19.

Saran

Pelajaran dari pengelolaan piutang melalui restrukturisasi kredit Bank XYZ adalah bahwa konsistensi dalam penerapan prinsip kehati-hatian dalam pemilihan nasabah untuk penyaluran pinjaman terbukti memberikan kontribusi dalam penurunan rasio piutang nonperforming, meskipun dalam kondisi Pandemi Covid-19. Penelitian kedepan disarankan dapat mengelaborasi bagaimana penerapan prinsip kehati-hatian ini dilakukan dalam konteks kondisi normal dan pandemik.

\section{DAFTAR PUSTAKA}

Azwar, M. (2021). STRATEGI PENANGANAN PEMBIAYAAN BEMASALAH PADA PEMBIAYAAN MURABAHAH di MASA PANDEMI COVID-19. Zhafir Journal of Islamic Economics, Finance, and Banking, 3(1), 1-14.

Irawan, F., \& Erdika, F. A. P. (2021). ANALISIS ATAS PENERAPAN PERATURAN PEMERINTAH NOMOR 23 TAHUN 2018 DI KANTOR PELAYANAN PAJAK PRATAMA MALANG SELATAN. Jurnal Pajak Indonesia, 5(No.1), 57-66.

Prabowo, A. (2020). Siaran Pers: OJK Keluarkan Panduan Penerapan PSAK 71 dan PSAK 68 untuk Perbankan di Masa Pandemi Covid -19. https://www.ojk.go.id/id/berita-dankegiatan/siaran-pers/Pages/Siaran-Pers-OJK-Keluarkan-Panduan-Penerapan-PSAK71-dan-PSAK-68-untuk-Perbankan-di-Masa-Pandemi-Covid--19.aspx

Puspita, A. A., Alzanah, N. M., \& Sarikuswati, S. (2020). Analisa Perpanjangan Restrukturisasi Kredit Terhadap Likuiditas Perbankan Sebelum dan Sesudah Pandemi Covid 19. Jurnal Aktiva: Riset Akuntansi Dan Keuangan, 2(3), 37-45.

Retnowati, M. S., Azmi, M. U., \& Munawaroh, H. (2021). Restrukturisasi Sebagai Sarana Negosiasi pada Pembiayaan Macet Jual Beli Angsuran di BMT IKPM Ponorogo. $A L$ IQTISHADIYAH Jurnal Ekonomi Syariah Dan Hukum Ekonomi Syariah, 7(1).

Sari, L. M., Musfiroh, L., \& Ambarwati. (2020). Restrukturisasi Kredit Bank Daerah X Pada Masa Pademi Covid-19. Jurnal Mutiara Madani, 08(1), 46-57. 


\section{JURNALKU}

Volume 1 No. 3, September 2021

Septriawan, M. R., Mulyani, S., \& Iqbal, M. (2021). Pengaruh Rektrukturisasi Kredit di Masa Pandemi Covid-19 Terhadap Pendapatan pada Perusahaan Perbankan Yang Terdaftar Di Bursa Efek Indonesia. Ekonomis: Journal of Economics and Business, 5(1), 94. https://doi.org/10.33087/ekonomis.v5i1.266

Setiawan, A., \& Ali, H. (2021). Restrukturisasi Pembiayaan Selama Pandemic Covid-19 di Bank Muamalat Madiun. An-Nisbah: Jurnal Perbankan Syariah, 2(1), 68-81. https://ejournal.iaiskjmalang.ac.id/index.php/nisbah/article/view/232

Setiawati, N. U. (2021). Kebijakan Restrukturisasi Pembiayaan Murabahah Bermasalah pada Nasabah UMKM Akibat Pandemi Coronavirus Disease 2019 (Covid-19). Notaire, 4(2), 235. https://doi.org/10.20473/ntr.v4i2.26122

Sukerta, I. M. R., Nyoman, I., Budiartha, P., \& Arini, D. G. D. (2021). Restrukturisasi Kredit terhadap Debitur Akibat Wanprestasi karena Dampak Pandemi COVID-19. Jurnal Preferensi Hukum, 2(2), 326-331.

Surono, B. A. A., Rahayu, S. M., \& A, Z. Z. (2015). Pengelolaan Piutang Yang Efektif Sebagai Upaya Meningkatkan Profitabilitas (Studi Kasus Pada Perusahaan CV Walet Sumber Barokah Malang Periode 2012-2014). Jurnal Administrasi Bisnis S1 Universitas Brawijaya, 28(1), 15-24.

Yakub, \& Firdaus, R. A. (2020). PRESS RELEASE - DAMPAK PANDEMI COVID-19 TERHADAP PENERAPAN ISAK 102 PENURUNAN NILAI PIUTANG MURABAHAH. http://iaiglobal.or.id/v03/files/file_berita/IAI - Press Release Covid19 dan ISAK 102.pdf 